\title{
Journal of Palaeogeography (English Edition) will be published in the first quarter of 2012
}

Approved by the General Administration of Press and Publication of the People's Republic of China, the Journal of Palaeogeography (English Edition) will be published in the first quarter of 2012. The Journal of Palaeogeography (English Edition) is by the competent authorities of Ministry of Education of the People's Republic of China, and sponsored by China University of Petroleum (Beijing) and Science Press Limited Corporation. Journal of Palaeogeography (English Edition) mainly publishes original research papers related with palaeogeography, including lithofacies palaeogeography, biopalaeogeography, tectonopalaeogeography, sequence stratigraphy and palaeogeography, Quaternary palaeogeography, human history palaeogeography, past and present environments and human civilization, sedimentology, sedimentary environments, sedimentary facies, palaeoecology, palaeotectonics, palaeoearthquake, palaeogeomorphology, palaeoclimatology, palaeohydrology, palaeokarst, paleosol, research methods and techniques of palaeogeography, and papers of the prediction, exploration, and development in petroleum, natural gas, coal, other metal and non-metallic resources. The website of the journal is: http://gdlxb.cup.edu.cn/, and email is: Jpalaeo1999@163.com. 